\title{
FORMS OF MOBILITY AND MOBILE FORMS
}

\author{
Introduction to the Forum Kritika on Literary Liquidities I
}

\author{
Maria Luisa F. Torres Reyes \\ University of Santo Tomas \\ lu2reyes2x@gmail.com
}

\begin{abstract}
About the Author
Maria Luisa F. Torres Reyes is professor at the University of Santo Tomas (UST), where she is also appointed scholar-in-residence and editor-in-chief of UNITAS, the university's peerreviewed online international journal of advanced research in literature, culture, and society. UNITAS is the oldest extant multidisciplinary journal in the Philippines, established in 1922. At the Ateneo de Manila University, where she was full professor at the English Department for many years, she is the Founding Editor and Editor Emerita of the widely-indexed international journal Kritika Kultura. She is the author of Banaag at Sikat (2010), the award-winning book of literary criticism on the first "socialist" novel in Asia of the same title, and SipatSalin (2012), a collection of her poems and their translations in various foreign and local languages. In her international publications, her scholarly interests and publications include the exploration of the ways in which "Western" ideas and literary and critical categories-like the theories of Bertolt Brecht, a major German theater theoretician and practitioner-have been "refunctioned" in the Philippines and other non-Western contexts. Active in various international professional organizations of academics, she has founded an international network of scholars, teachers, and artists, the Cultural, Literary, and Art Studies Society, Inc. (CLASS), which meets regularly in colloquia, working together toward undertaking international collaborative research and publishing co-authored works in literary and cultural studies. She is currently the president of CLASS and a member of the editorial board of a number of international journals on literature, culture, and the arts.
\end{abstract}


This special section of Kritika Kultura is the first of two parts on "literary liquidity," inspired mostly by Zygmunt Bauman's concept of "liquid modernity." The second part will come out in a subsequent issue. Drawing from Bauman, modern literary and cultural texts are analyzed for their "protean" possibilities as "forms of modern life," their malleability and multifacetedness in their common "fragility, temporariness, vulnerability and inclination to constant change" despite their diversity (viii-ix). Explored, therefore, are the supple and nimble textual representations of the phenomenon of mobility in today's postcolonial world which stretches across national boundaries and geopolitical locations resulting in transformations that are at once social and figural.

The papers for this special section were originally written for the 4th colloquium entitled "Post/colonial Places/Spaces," hosted by Universitas Kristen Indonesia. It was organized by the Cultural, Literary, and Arts Studies Society, Inc. (CLASS) held in Jakarta on March 1 and 2, 2019.

CLASS aims to promote and facilitate the sharing of ideas and expertise between and among researchers, scholars of literary, cultural and art studies, as well as faculty members of literature, composition and rhetoric, creative writing, culture, the arts and related fields of study like language studies and critical pedagogy, in institutions of higher learning and senior high school. It has strong and active international linkages with which it runs a series of international colloquia which were held in Yogyakarta and Jakarta, Indonesia, South Korea, and Japan, on various themes.

Titled "Literary Liquidities," the 2019 colloquium was co-sponsored by Academy of Mobility Humanities of Konkuk University (AMH), in collaboration with the University of Santo Tomas, Ateneo de Manila University, University of San Carlos, Cebu City, Universitas Sanata Dharma, and Universitas Indonesia.

The questions this colloquium wished to address included, among others:

1. In what ways are the dynamics and processes of globalization represented in literary and cultural texts through styles, rhetorical modes, genres, platforms, adaptations, and so on?

2. What bearing do they have on each other in ways that globalization is rendered in literary terms (i.e., fictionalized, narrativized, dramatized or poeticized, and thematized)? 
3. What transformations have resulted from real and metaphorical mobility in globalization, through such actual and social processes and textual strategies as displacement, substitutions, translation, shifts in platforms, and so on?

The two parts of the Forum Kritika on Literary Liquidities will be drawn from the following papers delivered in the colloquium:

- "Media(ted) Liquidities: Films into Novels" by Dr. Joyce L. Arriola

- "Literary Liquidity, Katresnanism, and the making of Indonesian Political Islam: The Voice of BBC Monitoring" by Dr. Antonius Herujiyanto

- “Transnational Filipino-German Marriage Migration Mobility” by Dr. Ma. Socorro Q. Perez

- "(Re)Duplicating Family Rituals as a Site of Ethnic, Class, and Gender Struggles in A Bit of Earth and The Song of Silver Frond" by Dr. Sri Mulyani

- “Islamic Butcher Shop Read as a Refugee Novel” by Dr. Jooyoung Kim

- "Ethnicity and Imagined Indonesia in Literature and Political Discourse" by Dr. Paulus Sarwoto

- "The Burden of Globalization: Diasporic Dimensions in Peter Bacho's Cebu and Elaine Castillo's America is Not the Heart" by Dr. Hope Sabanpan-Yu

- "Migrant Texts and Postcolonial Misreadings in Gina Apostol's The Revolution According to Raymundo Mata and Gun Dealer's Daughter" by Ma. Gabriela P. Martin, MA

- "Fluidity of Life and Society in Nonfiction Works Set in the Philippine Islands" by Francis C. Sollano, MA

- "Colonial Mobilities and the Politics of Non-Places" by Dr. Jinhyoung Lee

- "Textual Mobility and Mobile Textuality: from The Canon to Cyberspace" by Prof. Maria Luisa F. Torres Reyes

- “The Concept of 'World Literature' in Philippine Literary History” by Dr. Ramon G. Guillermo 
- "Globalization and Liquidity in Indonesian Literature" by Prof. Melani Budianta

- "Mobility in the Work of Haruki Murakami, Focusing on Dance Dance Dance as a Narrative of Mobility" by Prof. Inseop Shin

The papers in the Forum Kritika address different aspects of "literary liquidity" as follows:

"Channeling the Cinematic in Manuel Puig's Betrayed by Rita Hayworth" by Joyce L. Arriola deals with textual mobility as the theoretical and methodological bedrock of adaptation studies. In this specific type of transfer from one medium to another, the usual site of critique flows from literary source to film or any other media where the cultural status of the precursor text determines or influences the kind of reception given to the receiving or target text. However, with the fluidities of narratives taking place within literary and media cultures, films and other products of mass media have become a source of inspiration as well as challenges to novelists in the past decades. As such, the paper, which analyzes the impact of film on the modern Argentinian novel, is noteworthy across multiple formal considerations. Between filmic and fictional conventions is the generic fluidity that characterizes Puig's novel in which he explores the filmic conventions he saw as a child growing up in an Argentinian pampa in the 1960 s in a novelistic medium. Drawing from both Hollywood and local films, cinematic conventions such as dialogues, monologues and one-sided conversations are appropriated as narrative devices in Betrayed by Rita Hayworth. However, the dynamics of literary liquidity enabled by Puig's novel at play as it utilizes filmic devices are not merely a matter of transposition of the filmic devices to novelistic narratives nor is it simply about capturing the illusive effect of mindless movie-going on the consciousness of a community, but more of the creation of a new kind of expression-even of language-for modern Latin American novel that attests to the fluidities of impulses, influences and textualities and how they interpenetrate genres of culture to give rise to creative production.

“The Burden of Globalization: Diasporic Dimensions in Peter Bacho's Cebu and Elaine Castillo's America Is Not the Heart" by Hope Sabanpan-Yu focuses on the experience of diasporic mobility which is one of the distinguishing concerns of contemporary fiction that is associated with globalization. In novels such as Cebu and America Is Not the Heart, issues of culture and identity are not only foregrounded but also resignified as diasporic people encounter different situations where their sexuality, religion, gender, language and economic status realign along diverse ways and affect their lives in the new country. Literary liquidity marks the 
process of re-signification in these novels if viewed from the perspective of a global community where diasporic experiences are deemed to be mobile and provisional. From this vantage point, this paper attentively explores how mobility changes and continues to change its nature and disrupt stable constructs of identity.

Finally, "Reimagining the Fluid Categorization of the Communist, Chinese, and Jews in Umar Kayam's Stories" by Paulus Sarwoto addresses the idea of mobility in terms of social class, racial, religious, and geographical mobilities. Class mobility is exemplified by the Javanese noble figures transgressing class boundaries in solidarity with the common people through marriage or sharing their artistic talent in the service of their cause. Unfortunately, in the wake of the 1965 coup, sudden political realignments reframed such forms of solidarity as signs of treason against the state. As a result, historically this political reversal forced some Indonesians to leave for abroad as the New Order government accused them of supporting the Old Order, revoking their passports, becoming exiles, and rendering them stateless. These exiles are represented in a fictional figure of a Javanese Muslim who is made aware of the instability of racial and religious categories, as shown by his marriage to a Jewish American girl. The analysis of this fiction which is set in Java suggests how essentialist notions based on racial and religious categories are not tenable anymore and that transnational mobility, albeit by force, is fast taking its "place." As Bill Ashcroft argues, "the paradox of global culture is that it makes itself 'at home' in motion rather than in place."

\section{CONCLUSION: FORMS OF MOBILITY AND MOBILE FORMS}

Drawing from Bauman, it may be said that in postcolonial contexts like the Philippines and Indonesia, the movement between colonial forms and postcolonial realities has taken the form of a shift from "solid modernity to a more liquid form." In liquid modernity, constructing a durable identity that coheres over time and space becomes increasingly impossible, according to Bauman.

As Sabanpan-Yu indicates, "literary liquidity marks the process of re-signification" of texts if viewed from the larger context of a "global community where diasporic experiences are deemed to be mobile and provisional." From this vantage point, this paper attentively explores how mobility changes and continues to change its nature and disrupt stable constructs of identity. Sarwoto addresses the intersectionality of mobility "in terms of social class, racial, religious, and geographical mobilities" in his critique of "how essentialist notions" of a coherent durable identity "based on racial and religious categories are not tenable anymore and that transnational mobility, albeit by force," is fast taking its place. A kind of aesthetic of mobility 
which is, according to Merriman and Pearce, "integral to, and expressive of, specific art forms and textual practice." Traversing points A and B, such an aesthetic is not a neutral and passive space, it attests, instead, as Arriola states, "to the fluidities of impulses, influences and textualities and how they interpenetrate genres of culture to give rise to creative production." In this sense, to quote Merriman and Pearce, "the idea of mobility and movement as simply the subjects/objects of representation" is revalued as "the basic conceptual 'building-block' of thought as well as of the lifeworld in general." Indeed, through all these literary liquidities, following Marx, as often quoted, "all that is solid melts into air," in the life-world of modern society as it does in literature today under a postcolonial and globalized world. 


\section{Works Cited}

Bauman, Zygmunt. Liquid Modernity. Polity Press, 2012.

Cresswell, Tim. On the Move. Routledge, 2006.

Merriman, Peter, and Lynne Pearce. "Mobility and the Humanities." Mobilities, vol. 12, no. 4, 2017, pp. 493-508. Taylor E Francis Online, doi: 10.108o/17450101.2017.1330853. Accessed 1 Oct. 2019. 